\title{
Growth spillover: a spatial dynamic panel data and spatial cross section data approaches in selected Asian countries
}

\author{
Sahar Amidi ${ }^{*}$, Ali Fagheh Majidi ${ }^{2}$ and Bakhtiar Javaheri ${ }^{2}$
}

\begin{abstract}
One of the most fundamental issues worldwide is the economic interdependence of countries which affects their economic growth. Some new growth theorists such as Mankiw et al., Islam, Ertur and Koch, Lee, Yu and Yu Ho et al. consider geographical proximity and trade as spatial variables. This study aims to investigate the spatial effects of geographical distance on economic growth using the spatial dynamic panel data model and the spatial cross section data model for the period 1992-2016 in selected Asian countries. The findings demonstrate that the effect of spatial spillover or spatial dependency is one of the main causes of economic growth spillovers. In the spatial dynamic panel data model, log of gross domestic product (GDP), gross fixed capital formation and growth rate of labor force had negative, positive and negative impacts on economic growth, respectively. In the spatial cross-sectional data models including human capital, log of GDP, gross fixed capital formation and growth rate of labor force had negative impacts on economic growth, while in a model without human capital log of GDP, gross fixed capital formation and growth rate of labor force, respectively, had positive and negative effects on economic growth.
\end{abstract}

Keywords: Economic growth, Spatial econometrics, Spillover effects, Human capital, Asia

JEL Classification: C21, O47, O53, R11

\section{Introduction}

Economic growth and its determinants are fundamental for every country. Therefore, it is essential to study the influences of economic growth from different angles. Branches of economics dealing with the analysis of economic growth category, its causes and developments in geographical space have been essential topics of economics. Hence, it is necessary to unify geography and new growth theory, or at least to develop some junction models. The standard neoclassical economic growth model was developed by $[30,31]$ in the 1950 s. In that model, the saving rate and the Malthusian labor growth are exogenously given. Solow proposed a new analysis of growth model that is in many ways consistent with the

\footnotetext{
*Correspondence: sahar.amidi@etu.univ-orleans.fr

${ }^{1}$ Universite D'Orleans, 45000 Orléans, France

Full list of author information is available at the end of the article
}

neoclassical growth model. The Solow-Swan model is believed to show how the growth of capital stock, growth in the labor force and progress in technological interactions affect a nation's total output. The model illustrates supply of goods based on a production function of constant returns to scale, the diminishing returns of the scale of each factor of production and substitution between the factors. These functions are combined with the constant rate of payback and create a general equilibrium model [1]. Labor grows at a constant rate, the level of technology and savings rate are constant over time, and capital depreciates at a positive constant rate (that is, at each point in time, a constant fraction of the capital stocks wear out and therefore can no longer be used for production). In each second, the capital stock is a key determinant of the economy's output, but the capital stock can alter and this can lead to economic growth. Since Solow and Swan's theory was developed, a vast body of 
literature has been written on growth theory and different generations of models have been considered (see, for example, [6]). This paper firstly examines the neoclassical Solow-Swan hypothesis (does not include human capital) that considers geographical proximity and secondly investigates the spatial Solow model that includes human capital.

The main conclusion of the Solow model is that the accumulation of physical capital cannot explain the extraordinary growth in per capita production or the geographical differences of per capita production. Suppose that the accumulation of productive capital is affected by the conventional channel, that is, capital has a direct contribution to production, which is equal to its final return value. In this case, according to the Solow model, the differences in per capita production are much greater than those that can be explained by the capital input. Different regions of the world are influenced by knowledge and technology spillover, communication, production and trade mobility factors which are not taken into consideration by the neoclassical growth model of Solow and Swan. Furthermore, empirical research on the regional development process does not take into consideration an area independent of adjacent regions because according to the first geographical law of Tobler [32] any location depends on a location and the places that are closer have the greatest impact on each other than places farther away; indeed, countries are complex in nature involving economic, social and spatial characteristics. Hence, it is necessary to incorporate the spatial dependence into any of our econometric models; therefore, the relationship between countries in the context of spatial dependence should be considered. In the Solow spatial model, knowledge of capital is included and capital comprises of a broad concept of both the physical and human. The finding of the current study is particularly important for governments to better understand the role of determinants on economic growth.

This paper is organized as follows: the introduction is outlined in the "Introduction" section, and "Review of literature and empirical studies" section presents the spatial growth model, the spatial weight matrix and the proposed hypotheses tests. "Methods" section includes the methodology and data. "Analysis" section discusses the estimation results, and "Results and discussion" and "Conclusions" sections conclude with some policy implications.

\section{Review of literature and empirical studies}

Nowadays, rapid economic growth heavily promotes the development of a country or region. Society puts great focus on development of economic growth. Therefore, many researchers study economic growth through different econometrics models and approaches. In studies by Mankiew et al. [26], the spatial effects of economic growth were estimated with cross-sectional data for 121 countries classified into three groups of non-oil, middleincome and OECD countries for the period 1960-1985. They added human capital to their model to examine its effect on the model of Solow growth. Islam [21] used panel data approach in his study and advocated studying growth convergence. He added the Mankiew, Romer and Weil model convergence into a panel data model with individual (country) effects but did not estimate the effect of human capital on economic growth. Scarpello and Ritelli [29] improved the neoclassical economic SolowSwan model [31] replacing its Malthusian manpower law with the Verhulst (logistic) law. Camacho and Zou [10] solved a Solow model on continuous time and space. They proved the existence of a solution to the problem and its convergence of a stationary solution. Brito [9] addressed unbounded growth in a spatially heterogeneous world. They presented a continuous time-continuous space case extension of the Solow [30] model where capital and labor mobility generate two spatial interacting forces. First, endogeneity generates a distributed balanced growth path which they assumed to be exogenous. Their approach, formalized by a nonlinear parabolic partial differential equation allowed for an integrated treatment $\beta$ of and $\sigma$-convergence studied in growth theory, and dispersion and agglomeration studied in the new geographical economics. Guerrini [19] analyzed the dynamics of the Solow-Swan growth models when the labor growth rate is inconstant but variable and bounded over time. Ertur and Koch [16] studied the theoretical growth model by considering technological interdependence and spillover effects using cross-sectional data approach. In Lee and Yu's study [23], the effect of physical capital, the growth rate of a labor force and human capital were not evaluated in determining economic growth. In the study of Yu Ho et al. [33], the spatial effects of geographical distance and trade were measured only through the convergence of dynamic panel data onto economic growth and the cross-sectional effects of the data were not evaluated. Neto and Claeyssen [28] considered labor mobility in the spatial Solow model of economic growth. Their finding illustrated that labor spreads from regions of higher density of labor to regions of lower density of labor. In addition, they found that workers move from regions with a lower density of capital to regions with a higher density of capital and the labor force grows following a logistic law. Benos et al. [8] obtained and analyzed data regarding seven European regions for the period 1990 and 2005. Spillovers, according to their results, are critical for European regional growth irrespective of the measure of proximity; thus, regions surrounded by 
dynamic entities are likely to grow faster than otherwise. Moreover, their results underline the need for coordinated EU policies aimed at higher physical and human capital accumulation taking into account regional synergies. Erdem et al. [15] developed an augmented version of the Solow growth model which included gender shares by using panel autoregressive distributed lag approach for 122 countries during 1990-2014. They found that income per capita increases with the share of women in employment. Ciftci et al. [11] studied the role of taxation on long-run income performance using the common correlated effects (CCE) for 30 OECD countries during the period 1995-2016. They discovered that only consumption tax has a statistically significant negative effect on long-run income. Moreover, their results indicated that taxation has heterogeneous effects on income as a result of the type and sign of the tax coefficients $b$ heterogeneous for the country-specific results. Amidi and Fagheh Majidi [1] investigated the geographical proximity, trade and economic growth with a spatial econometrics approach for EU countries over the period 1992-2016. They recognized that spatial relationships across countries and the spatial effects of trade are quite relevant. Furthermore, a country's economic growth is actually affected by the performance of its neighbors and trade partners. In comparison with existing studies, the innovatory aspects of this research are as outlined below:

1. The analyses of previous studies are extended to include the timeframe $1992-2016$ in order to analyze the contribution of effective factors in economic growth.

2. Previous studies did not employ a combination of spatial dynamic panel data and spatial cross section data and solely investigated spatial cross section data for spatial spillover of economic growth.

3. In previous studies of growth models, human capital and gross fixed capital formation were not separated.

4. Previous studies did not use XSMLE models for estimating panel models (in the present research, five types of spatial models are included in the package making it more complex than other packages. In other research, only four kinds of spatial models are used.

\section{Methods}

To investigate the impact on growth spillover in 19 countries in Asia, the factors affecting growth were first determined. Using aggregate data of different geographical regions (countries) in the regression analysis, the existence of spatial autocorrelation in the error terms seems to be inevitable. In other words, the spatial heterogeneity between the studied countries is of great importance as well. The term spatial heterogeneity refers to deviation from the existing relationships between observations at the geographical level. For this reason, due to the existence of spatial heterogeneity and spatial autocorrelation in spatial studies, spatial econometrics should be used. To describe the spatial heterogeneity, a linear relationship for the spatial cross section data model was considered as follows:

$$
y_{i}=W_{i} \beta_{i}+\varepsilon_{i}
$$

To describe the spatial heterogeneity, a linear relationship for the spatial dynamic panel data model was considered as follows:

$$
y_{i t}=W_{i} \beta_{i t}+\varepsilon_{i t}
$$

where $i$ refers to the countries collected at $i=1, \ldots, n$ points in space, $t$ is the period at $t=1, \ldots, m, W_{i}$ represents a matrix of explanatory variables (distance) with a related set of $\beta_{i}$ and $\beta_{i t}$ parameters, $y_{i}$ and $y_{i t}$ (economic growth) are the dependent variables at countries (or location) $i$ and time $t$, and $\varepsilon_{i}$ and $\varepsilon_{i t}$ indicate a stochastic disturbance (random error). Equations (1) and (2) represent the simple spatial cross section data model and the simple spatial dynamic panel data model, respectively [24].

Actually, causal relationships compared to single equation cross-sectional setting core on spatial econometrics in the long term. Panel data typically contain more variation and often less collinearity among the variables. Using the panel data results in greater availability of degrees of freedom and hence increases efficiency in the estimation. Also, panel data allow the specification of more complicated behavioral hypotheses including effects that cannot be addressed using pure cross-sectional data [14].

For distance matrix, the following four methods are used to represent spatial location: (1) determining location on screen coordinates, (2) vector of distances, (3) geographically weighted regression (GWR) method and (4) GeoDist. This study used GeoDist. GeoDist provides several geographical variables, bilateral distances measured using city-level data to account for the geographical distribution of the population of each nation. As spatial matrix has been used to demonstrate the spatial contiguity in this study, spatial contiguity needs to be reflected as a matrix in the model. Thus, geographically weighted regression method was used to weigh each variable. In this method, in Eq. (3), economic growth is represented by $y$ where $N \times 1$ vector of dependent variable observations are collected at $\mathrm{n}$ points in space, $X$ is $N \times K$ matrix of explanatory variables and $\varepsilon_{i} N \times 1$ is vector of normal errors which has constant variance. Given $W_{i j}$ represents $N \times N$ diagonal matrix containing distance-based weights 
reflecting the distance between countries I and other countries, GWR model can be as follows:

$$
W_{i j} y=W_{i j} X \beta_{i}+\varepsilon_{i}
$$

where $i$ in $\beta_{i}$ is the indicator of $i \times 1$ vector of $i$ observation related parameter. The GWR model estimates $n$ cases of such vectors of different countries each representing an observation for spatial cross section data model [27].

This technique describes the relative position in the space of a single regional observation unit compared to other units. The criteria of contiguity were determined using the information obtained from a distance between capitals of the countries. In most spatial economics studies, zero and one matrix is used for studying spatial effect. In this matrix, $N \times N$ ( $N$ number of the country), if countries are in proximity to each other number one was used and for other cases zero was used. Then, a standard matrix was created where sum of each horizontal row should equal one. However, this matrix has flaws because of giving similar weight to all countries. Spatial weight matrix was used to solve this problem. In this matrix, each diagonal element equal $\frac{1}{d_{i j}} \cdot d_{i j}$ is the distance between the capital of two countries. With this matrix, the proximity variable was used for studying spatial effect on growth.

Three different types of interaction effects on a spatial econometric model particularly in a standard linear regression model could be demonstrated: endogenous interaction effects among the dependent variables $(Y)$, exogenous interaction effects among the independent variables $(X)$ and interaction effects among the error terms $(e)$ [14]. In the present research, five models were used for the spatial panel data model (SAR, SEM, SAC, SDM and GSPRE) and four models were used for the spatial cross section data model (SAR, SEM, SAC and SDM). SAR is the spatial lag model, also known as the spatial autoregressive model, and SEM is the spatial error model. Both of these models have one type of interaction effects. However, SAR contains endogenous interaction effects and SEM contains interaction effects among the error terms. In the study by Anselin and Bera [2], the testing procedure for a spatial lag or a spatial error model was based on robust Lagrange multiplier tests. SAC is the spatial autoregressive model with autoregressive disturbances models that include both endogenous interaction effects and interaction effects among the error terms [22, 25]. When the spatial weights matrix is used to specify the spatial lag and the spatial error structure it is the same as the spatial Durbin model (SDM). GSPRE is the generalized spatial panel random effect model which includes the spatial models referred to as the SDM model in panel mode. In fact, this model has no limitations and all variables are independent except for weight disturbance $[14,24]$.

The general form of the spatial panel model is as follows [7]

$$
\begin{aligned}
& y_{i t}= \alpha+\tau y_{i t-1}+\rho \sum_{j=1}^{n} w_{i j} y_{i t}+\sum_{k=1}^{K} x_{i t k} \beta_{k} \\
&+\sum_{k=1}^{K} \sum_{j=1}^{n} w_{i j} x_{j t k} \theta_{k}+\mu_{i}+\gamma_{t}+v_{i t} \\
& v_{i t}=\lambda \sum_{j=1}^{n} m_{i j} v_{i t}+\varepsilon_{i t} \\
& i=1, \ldots, n \\
& t=1, \ldots, T
\end{aligned}
$$

where $\theta$ represents a $K \times 1$ vector of fixed but unknown parameters to be estimated, $\lambda$ is the spatial autocorrelation coefficient, $\rho$ is the spatial autoregressive coefficient, $W_{i j}$ is a nonnegative $N \times N$ matrix describing the non-stochastic spatial weights matrices configurations or arrangement of the units in the sample which are the spatial parameters of the model, $t=1,2, \ldots, T, y_{i t}=\left(y_{i t}\right.$, $\left.y_{2 t} \ldots, y_{i t}\right)^{\prime}, X_{i t k}$ is an $i \times k$ matrix of non-stochastic regressors, $X_{j t k}$ is an $j \times k$ matrix of non-stochastic regressors, $v_{i t}=\left(v_{i t}, v_{2 t}, \ldots, v_{i t}\right)^{\prime}$ are $i \times 1$ column vectors, $v_{i t}$ 's are i.i.d. across $I$ and $t$ with zero mean and variance $\sigma_{0}^{2}, \alpha$ is an $i \times 1$ column vector of individual fixed effects, $\tau$ is a scalar indicating a time effect, $\beta_{k}$ is the indicator of $k \times 1$ vector of k observation related parameter, $\varepsilon_{i t}$ is $N \times 1$ vector of normal errors $\mu_{i}$ and $\gamma_{t}$ illustrate the spatial fixed effects and time-period fixed effects, respectively. $\varepsilon_{i t}, \mu_{i}$ and $\gamma_{t}$ are random variables which are independent of each other $[4,14,34] . \theta, \lambda, \rho$ are the spatial parameters. Given $\theta=0$, the model is SAC; $\lambda=0$ is SDM; $\lambda=0$ and $\theta=0$ are SAR; $\rho=0$ and $\theta=0$ are SEM and $\lambda=0, \theta=0$ and $\mu_{i}=\emptyset \sum_{j=1}^{n} w_{i j} \mu_{i}+\eta_{i}$ represent GSPRE. In fact, all of the models consider a weight matrix but the considered weight matrix of each model is different.

After one by one estimation of five stipulation of Eq. (5), the "Hausman test" can be used to select "Random" versus "Fixed Effects" $[4,20]$. It is noteworthy that the Hausman test can be applied to SAR, SDM and SEM models but cannot be applied to SAC and GSPRE models because the former is only assumed to be fixed and the latter is just random [13]. Generally, the LR test could be used to select a more appropriate functional form out of the five models: SDM, SAR, SEM, SAC and GSPRE. In order to compare the models using the LR test, one model was considered unrestricted and other ones considered restricted. Taking into account the number of 
constraints, the following five ways for comparing the models were possible: (1) SDM unrestricted model versus SAR restricted model which distinguished the constraint of the weight matrix of variables; (2) SAC unrestricted model versus SEM restricted model which showed the constraint of the spatial correlation coefficient $(\rho)$; (3) SAC unrestricted model versus the SAR restricted model which illustrated the constraint of the spatial correlation coefficient between error terms $(\lambda)$; and (5) GSPRE unrestricted model versus the SEM restricted model. Here, the constraint is the spatial correlation coefficient between distance variables $(\theta)$. LR test is shown as follows:

$$
\mathrm{LR}=-2\left(\operatorname{Ln} L_{\mathrm{R}}-\operatorname{Ln} L_{\mathrm{UR}}\right)_{\left(x^{2}, k\right)} \approx x_{(\mathrm{M})}^{2}
$$

In the LR test, the hypothesis $\mathrm{H}_{0}$ means accepting the restricted model and the hypothesis $\mathrm{H}_{1}$ means accepting the unrestricted model. Thus, if the amount of LR statistic is more than the Chi-square table (with $M$ degree of freedom being the number of constraints), $\mathrm{H}_{0}$ will be rejected, rejecting $\mathrm{H}_{0}$ does not mean that a spatial econometrics model is necessary but that it should be considered [18]. Finally, among the five functional forms, the form chosen is that which is superior in two criteria: the number of significant coefficients and higher $R^{2}$.

In a spatial econometric model, the effect of an explanatory variable change in a specific unit will affect not only that unit but also its neighbors. Hence, the coefficient $\beta$ is just a component of the total (marginal) effects to which the effect of the spatially lagged explanatory variable should be added. More precisely, for each regressor, $N \times N$ matrix of coefficients existed, indicating how a change in that regressor influences all the units in the sample. This implies that if $K$ is the number of controls in the model, $K$ matrices of dimension $N \times N$ of indirect effects and $K$ vectors of dimension $N \times 1$ of direct effects will occur. The latter is the diagonal elements of the $N \times N$ matrix of total effects and indicate how the dependent variable changes into unit $i$ given the changes in the $k$ th regressor in unit $i$. Indirect effects are the off-diagonal elements of the matrix of total effects and indicate how changes in the explanatory variable in unit $i$ affects the dependent variable in unit $j$ through a feedback process (see [12]). Furthermore, it should be noted that the estimated direct and indirect effects might go in opposite directions, thus looking only at one of them might not be sufficient [3].

The spatial model of this research is based on theoretical literature of research and previous studies derived from the model of Mankiw et al. [26] which is in the form of relation (7)
Table 1 Descriptive statistics of variables during 19922016

\begin{tabular}{|c|c|c|c|c|c|}
\hline & $N+g+\delta$ & Human capital & LNC & $\operatorname{LNGDP}(t-1)$ & DLNGDP \\
\hline \multicolumn{6}{|c|}{19 country } \\
\hline Min & -4.58 & 0.33 & 21.77 & 8.06 & -0.22 \\
\hline Max & 10.8 & 1.76 & 29.08 & 11.92 & 0.16 \\
\hline Mean & 2.09 & 0.93 & 25.04 & 10.39 & 0.02 \\
\hline SD & 1.78 & 0.27 & 1.56 & 0.89 & 0.04 \\
\hline
\end{tabular}

$$
\begin{aligned}
\Delta \ln Y_{i t}= & -\left(1-\mathrm{e}^{-a}\right) \ln Y_{i 0}-\frac{a\left(1-\mathrm{e}^{-c t}\right)}{1-a} \ln \left(N_{i}+g+\delta\right) \\
& +\frac{a\left(1-\mathrm{e}^{-c t}\right)}{1-a} \ln \left(S_{i}\right)+\left(1-\mathrm{e}^{-c t}\right) \ln A_{i 0}+g t
\end{aligned}
$$

It considers the Cobb-Douglas product function $Y_{t}=K_{t}^{\alpha} H_{t}^{\varphi}\left(A_{t} L_{t}\right)^{1-\alpha-\varphi}$ in the model with human capital and its $Y_{t}=K_{t}^{\alpha}\left(A_{t} L_{t}\right)^{1-\alpha}$ in the model without human capital, where $0<\alpha<1^{2}$. The labor augment technological progress $A$ grows at rate $g$ exogenously, i.e., $A_{t}=A_{0} \exp (g t)$, and the labor $L$ grows at rate $n$ exogenously, i.e., $L_{t}=L_{0}$ $\exp (n t)$. The explanatory variables include exogenous technical progress rate $(g)$, labor growth rate $(N)$, savings rate $(S)$ and capital depreciation rate $(\delta)$. An exogenous technical progress rate was assumed, and the capital depreciation rate was assumed to be constant across countries, i.e., $g+\delta=0.05$, as in Mankiw et al. [26], Islam [21], Ertur and Koch [16] and Yu Ho et al. [33].

\section{Analysis}

\section{Data}

In our model, the spatial dynamic panel data model and the spatial cross-sectional data were used for 19 countries. These countries were chosen because they had complete data. Because of missing data for estimating spatial models, most countries had to be omitted from this research. In addition, countries with incomplete datasets (i.e., 2 or 3 data missing) had to be omitted as Stata gave error when estimating the spatial model. The countries included were China, Cyprus, Egypt, Hong Kong, Indonesia, India, Iran, Japan, Korea, Lebanon, Malaysia, Pakistan, Philippines, Russian Federation, Saudi Arabia, Singapore, Thailand, Turkey and Vietnam. The data cover the period 1992-2016. The variables used were as follows: differential log of GDP as a proxy of economic growth $\left(\operatorname{DLNGDP}_{(t-1)}\right)$; gross fixed capital formation (constant 2010 US\$) (LNC); human capital (Human capital); combined growth rate of labor force, exogenous technical progress rate and capital depreciation rate $(N+g+\delta)$. All the research data were collected from the World Bank, CEPII, Penn World Table 9 (PWT 9.0)-Groningen University [17] and Barro-Lee [5] and 
Table 2 Results of selection model tests for economic growth during 1992-2016 without human capital

\begin{tabular}{|c|c|c|c|}
\hline $\begin{array}{l}\text { Hypothesis } \\
\mathrm{H}_{0} \text { (restricted } \\
\text { model) }\end{array}$ & $\begin{array}{l}\text { Hypothesis } \mathrm{H}_{1} \\
\text { (unrestricted } \\
\text { model) }\end{array}$ & The test result & $\begin{array}{l}\text { Value of the test } \\
\text { statistic ( } P \text { value) }\end{array}$ \\
\hline \multicolumn{4}{|c|}{$\begin{array}{l}\text { Hausman test (to select the random effects and the fixed effects } \\
\text { model) }\end{array}$} \\
\hline SDM random & SDM fixed & SDM fixed & $H=42.55(0.0000)$ \\
\hline SAR random & SAR fixed & SAR fixed & $H=11.59(0.0089)$ \\
\hline SEM random & SEM fixed & SEM fixed & $H=35.75(0.000)$ \\
\hline \multicolumn{4}{|c|}{ LR test (for nested models) } \\
\hline SAR fixed & SDM fixed & SDM fixed & $\begin{array}{l}\mathrm{LR}=91.383 \\
\quad(0.000)\end{array}$ \\
\hline SEM fixed & SAC fixed & SEM fixed & $\begin{array}{l}\mathrm{LR}=0.5284 \\
\quad(0.9126)\end{array}$ \\
\hline SAR fixed & SAC fixed & SAC fixed & $\begin{array}{l}\mathrm{LR}=302.1528 \\
\quad(0.000)\end{array}$ \\
\hline SEM random & GSPRE random & SEM random & $\begin{array}{l}\mathrm{LR}=1.575 \\
\quad(0.6651)\end{array}$ \\
\hline
\end{tabular}

expressed in natural logarithms. The descriptive statistics of variables are presented in Table 1.

SDM, SAR, SEM, SAC and GSPRE models as well as two fixed and random effects for all models were estimated. The results of the estimation of models are as follows:

In this model, economic growth, gross fixed capital formation, growth rate labor force, the log of GDP and human capital were significant in the estimation. In fact, they were the effective variables of the model.

According to Table 2, the Hausman test shows that in the SDM, SAR and SEM models, the fixed effects model is superior to the random effects model. Since in the three models, the fixed effects model was superior to the random effects model, the fixed effects model was considered more appropriate. Furthermore, the results of the LR test for selecting the more appropriate model are shown in Table 3. Based on the Hausman test, there were five models for the LR test and so comparisons could be made between the fixed SAR and fixed SDM models, between the fixed SEM and fixed SAC models, between the fixed SAR and fixed SAC models and also between the random SEM and random GSPRE models. Based on the results, SEM, SAC and SDM models in one state were fixed and in another were random. Based on the Hausman test, the last model was rejected because it had random effects. $R^{2}$ was $0.1701,0.1741$ and 0.0417 in the SAC, SEM and SDM models, respectively. Since the

Table 3 Estimation of panel spatial models during 1992-2016 for 19 countries with human capital

\begin{tabular}{|c|c|c|c|c|c|c|c|c|}
\hline \multirow[t]{2}{*}{ Variable } & \multirow{2}{*}{$\begin{array}{l}\text { GSPRE } \\
\text { random } \\
\text { effects }\end{array}$} & \multirow{2}{*}{$\begin{array}{l}\text { SAC fixed } \\
\text { effects }\end{array}$} & \multicolumn{2}{|l|}{ SEM } & \multicolumn{2}{|l|}{ SAR } & \multicolumn{2}{|l|}{ SDM } \\
\hline & & & Fixed effects & $\begin{array}{l}\text { Random } \\
\text { effects }\end{array}$ & Fixed effects & $\begin{array}{l}\text { Random } \\
\text { effects }\end{array}$ & Fixed effects & Random effects \\
\hline Constant & $\begin{array}{l}0.12 \\
(1.85)\end{array}$ & & & $\begin{array}{l}0.11 \\
(1.63)\end{array}$ & & $\begin{array}{l}0.05 \\
(0.67)\end{array}$ & & $\begin{array}{l}0.07 \\
(1.10)\end{array}$ \\
\hline $\left.\operatorname{LNGDP}_{t-1}\right)$ & $\begin{array}{l}-0.02^{* * *} \\
(-3.57)\end{array}$ & $\begin{array}{l}-0.09^{* * *} \\
(-6.56)\end{array}$ & $\begin{array}{l}-0.09^{* * *} \\
(-6.81)\end{array}$ & $\begin{array}{l}-0.02^{* * *} \\
(-3.31)\end{array}$ & $\begin{array}{l}-0.04^{* * *} \\
(-3.59)\end{array}$ & $\begin{array}{l}-0.005 \\
(-1.10)\end{array}$ & $\begin{array}{l}-0.09^{* * *} \\
(-6.70)\end{array}$ & $\begin{array}{l}-0.02^{* * *} \\
(-2.37)\end{array}$ \\
\hline LN capital & $\begin{array}{l}0.004^{* * *} \\
(1.60)\end{array}$ & $\begin{array}{l}0.04^{* * *} \\
(5.92)\end{array}$ & $\begin{array}{l}0.04^{* * *} \\
(6.08)\end{array}$ & $\begin{array}{l}0.004^{*} \\
(1.69)\end{array}$ & $\begin{array}{l}0.02^{* * *} \\
(2.91)\end{array}$ & $\begin{array}{l}0.0005 \\
(0.20)\end{array}$ & $\begin{array}{l}0.04^{* * *} \\
(5.19)\end{array}$ & $\begin{array}{l}0.009^{* * *} \\
(2.39)\end{array}$ \\
\hline$(N+0.05)$ & $\begin{array}{l}-0.007^{* * *} \\
(-7.22)\end{array}$ & $\begin{array}{l}-0.009^{* * *} \\
(-8.19)\end{array}$ & $\begin{array}{l}-0.008^{* * *} \\
(-8.39)\end{array}$ & $\begin{array}{l}-0.007^{* * *} \\
(-7.20)\end{array}$ & $\begin{array}{l}-0.005^{* * *} \\
(-5.72)\end{array}$ & $\begin{array}{l}-0.005^{* * *} \\
(-5.14)\end{array}$ & $\begin{array}{l}-0.009^{* * * *} \\
(-9.23)\end{array}$ & $\begin{array}{l}-0.008^{* * *} \\
(-8.19)\end{array}$ \\
\hline $\begin{array}{l}\text { LN human } \\
\text { capital }\end{array}$ & $\begin{array}{l}-0.01 \\
(-0.88)\end{array}$ & $\begin{array}{l}-0.02 \\
(-1.32)\end{array}$ & $\begin{array}{l}-0.02 \\
(-1.25)\end{array}$ & $\begin{array}{l}-0.01 \\
(-1.09)\end{array}$ & $\begin{array}{l}0.008 \\
(0.82)\end{array}$ & $\begin{array}{l}0.004 \\
(0.46)\end{array}$ & $\begin{array}{l}-0.04^{* * *} \\
(-2.01)\end{array}$ & $\begin{array}{l}-0.04^{* * *} \\
(-2.18)\end{array}$ \\
\hline $\left.\operatorname{LNGDP}_{t-1}\right)^{*} W$ & & & & & & & $\begin{array}{l}0.02^{* * *} \\
(6.08)\end{array}$ & $\begin{array}{l}0.005^{* *} \\
(1.81)\end{array}$ \\
\hline Capital ${ }^{*} W$ & & & & & & & $\begin{array}{l}-0.009^{* * * *} \\
(-4.11)\end{array}$ & $\begin{array}{l}-0.003^{* * *} \\
(-2.76)\end{array}$ \\
\hline$(N+0.05)^{*} W$ & & & & & & & $\begin{array}{l}0.003^{* * *} \\
(8.17)\end{array}$ & $\begin{array}{l}0.003^{* * *} \\
(7.19)\end{array}$ \\
\hline $\begin{array}{l}\text { LN human } \\
\text { capital* }^{*} W\end{array}$ & & & & & & & $\begin{array}{l}0.01^{* * *} \\
(2.81)\end{array}$ & $\begin{array}{l}0.01^{* * *} \\
(3.98)\end{array}$ \\
\hline$\rho$ & & $\begin{array}{l}-0.04 \\
(-0.89)\end{array}$ & & & $\begin{array}{l}0.27^{* * *} \\
(60.94)\end{array}$ & $\begin{array}{l}0.27^{* * *} \\
(60.06)\end{array}$ & $\begin{array}{l}0.27^{* * *} \\
(58.25)\end{array}$ & $\begin{array}{l}0.27^{* * *} \\
(58.20)\end{array}$ \\
\hline$\lambda$ & $\begin{array}{l}0.08^{* * *} \\
(6.63)\end{array}$ & $\begin{array}{l}0.1^{* * *} \\
(4.23)\end{array}$ & $\begin{array}{l}0.08^{* * *} \\
(6.28)\end{array}$ & $\begin{array}{l}0.08^{* * *} \\
(6.64)\end{array}$ & & & & \\
\hline$\emptyset$ & $\begin{array}{l}-0.18 \\
(-0.85)\end{array}$ & & & & & & & \\
\hline LNL & 943.99 & 988.56 & 988.12 & 943.40 & 836.87 & 799.31 & 886.37 & 838.86 \\
\hline
\end{tabular}

${ }^{*}{ }^{* *}$ and ${ }^{* * *}$ denote significance at $10 \%, 5 \%$ and $1 \%$ level. The numbers in the () are the $t$-statistic 
SEM model had the largest $R^{2}$, it was more likely to be accepted and as a result selected as the more appropriate model. In fact, the "fixed SEM model" compared to other spatial models better explains the impact of economic growth and spatial correlation.

According to Table 4, based on the SEM model, the coefficient of the variable log of GDP and the coefficient of gross fixed capital formation are negative and positive, respectively. When a country invests in technology and improves its technology, the return on investment is greater than the domestic interest it owns, productivity increases and neighboring countries also benefit. In other words, with the improvement of the situation of one or more countries in a region, all the countries in the region will benefit which will, in fact, create a positive growth cycle in the region. In addition, with the increase in physical capital, a country's production capacity increases and with economic growth, GDP growth increases. Capital spillover occurs from countries with high capital stock to countries of low capital stock. Moreover, when openness increases, capital flow rises also. The lesser amount of capital in developing countries results in a higher economic growth compared to developed countries. The coefficient of the growth rate labor force was negative. When the final productivity of the workforce is zero, the growth rate of the labor force will be negative leading to unemployment in a country. Therefore, more labor force entering the production process does not necessarily increase production. A rise in the growth rate of the labor force does not inevitably lead to greater production and GDP growth. The reason for this might be that the labor force growth rate has reached saturation point. On the other hand, in the Solow's models, economic growth increases due to the lower returns of capital to the workforce by increasing physical capital and reducing labor force growth rates. When measuring the factors affecting economic growth such as the formation of gross fixed capital formation and growth rate labor force, to avoid the heterogeneity variance, it is necessary to determine the position and proximity of the desired location that is measured by the model. The significance of these coefficients means that the meaning of spatial correlation in the performance relation is based on geographical location. Furthermore, the spatial autocorrelation coefficient, $\lambda$, indicates that the value of this coefficient is statistically significant and positive, so the geographical dimension is of particular importance between countries. It shows that in a period of time, countries which have a year's economic growth, on average, have the potential to grow more the following year. A country's economic growth will increase by $0.76 \%$ if the average weighted economic growth of its neighboring countries increases by $1 \%$.

According to Table 5, the Hausman test shows that in the SDM and SEM models, the fixed effects model was

Table 4 Estimation of panel spatial models during 1992-2016 for 19 countries without human capital

\begin{tabular}{|c|c|c|c|c|c|c|c|c|}
\hline \multirow[t]{2}{*}{ Variable } & \multirow{2}{*}{$\begin{array}{l}\text { GSPRE } \\
\text { random } \\
\text { effects }\end{array}$} & \multirow{2}{*}{$\begin{array}{l}\text { SAC fixed } \\
\text { effects }\end{array}$} & \multicolumn{2}{|l|}{ SEM } & \multicolumn{2}{|l|}{ SAR } & \multicolumn{2}{|l|}{ SDM } \\
\hline & & & Fixed effects & $\begin{array}{l}\text { Random } \\
\text { effects }\end{array}$ & Fixed effects & $\begin{array}{l}\text { Random } \\
\text { effects }\end{array}$ & Fixed effects & Random effects \\
\hline Constant & $\begin{array}{l}0.13^{* *} \\
(2.29)\end{array}$ & & & $\begin{array}{l}0.13^{* *} \\
(2.05)\end{array}$ & & $\begin{array}{l}0.03 \\
(0.53)\end{array}$ & & $\begin{array}{l}-0.03 \\
(-0.52)\end{array}$ \\
\hline $\operatorname{LNGDP}(t-1)$ & $\begin{array}{l}-0.02^{* * *} \\
(-4.15)\end{array}$ & $\begin{array}{l}-0.09^{* * *} \\
(-6.87)\end{array}$ & $\begin{array}{l}-0.09^{* * *} \\
(-7.17)\end{array}$ & $\begin{array}{l}-0.02^{* * *} \\
(-4.09)\end{array}$ & $\begin{array}{l}-0.04^{* * *} \\
(-3.50)\end{array}$ & $\begin{array}{l}-0.004 \\
(-1.02)\end{array}$ & $\begin{array}{l}-0.10^{* * *} \\
(-7.25)\end{array}$ & $\begin{array}{l}-0.02 * * * \\
(-2.78)\end{array}$ \\
\hline LN capital & $\begin{array}{l}0.003 \\
(1.45)\end{array}$ & $\begin{array}{l}0.04^{* * *} \\
(5.79)\end{array}$ & $\begin{array}{l}0.04^{* * *} \\
(5.94)\end{array}$ & $\begin{array}{l}0.004 \\
(1.54)\end{array}$ & $\begin{array}{l}0.02^{* * * *} \\
(3.31)\end{array}$ & $\begin{array}{l}0.0008 \\
(0.32)\end{array}$ & $\begin{array}{l}0.04^{* * * *} \\
(5.03)\end{array}$ & $\begin{array}{l}0.01^{* * *} \\
(2.93)\end{array}$ \\
\hline$(N+0.05)$ & $\begin{array}{l}-0.007^{* * *} \\
(-7.16)\end{array}$ & $\begin{array}{l}-0.008^{* * *} \\
(-8.11)\end{array}$ & $\begin{array}{l}-0.008^{* * *} \\
(-8.30)\end{array}$ & $\begin{array}{l}-0.007^{* * *} \\
(6.65)\end{array}$ & $\begin{array}{l}-0.006^{* * *} \\
(-5.81)\end{array}$ & $\begin{array}{l}-0.005^{\text {*** }} \\
(-5.18)\end{array}$ & $\begin{array}{l}-0.009^{* * *} \\
(-8.88)\end{array}$ & $\begin{array}{l}-0.008^{* * *} \\
(-7.55)\end{array}$ \\
\hline $\operatorname{LNGDP}(t-1)^{*} W$ & & & & & & & $\begin{array}{l}0.03^{* * *} \\
(6.58)\end{array}$ & $\begin{array}{l}0.003^{* *} \\
(2.35)\end{array}$ \\
\hline Capital* $W^{*}$ & & & & & & & $\begin{array}{l}-0.007^{* * *} \\
(-3.46)\end{array}$ & $\begin{array}{l}-0.003^{* * *} \\
(-2.76)\end{array}$ \\
\hline$(N+0.05)^{*} W$ & & & & & & & $\begin{array}{l}0.003^{* * *} \\
(7.73)\end{array}$ & $\begin{array}{l}0.003^{* * *} \\
(6.23)\end{array}$ \\
\hline$\rho$ & & $\begin{array}{l}-0.03 \\
(-0.70)\end{array}$ & & & $\begin{array}{l}0.27^{* * *} \\
(61.15)\end{array}$ & $\begin{array}{l}0.27^{* * *} \\
(60.13)\end{array}$ & $\begin{array}{l}0.27^{* * *} \\
(58.54)\end{array}$ & $\begin{array}{l}0.27^{* * *} \\
(58.55)\end{array}$ \\
\hline$\lambda$ & $\begin{array}{l}0.08^{* * *} \\
(6.64)\end{array}$ & $\begin{array}{l}0.09 * * * \\
(4.01)\end{array}$ & $\begin{array}{l}0.08^{* * *} \\
(6.44)\end{array}$ & $\begin{array}{l}0.08^{* * *} \\
(6.65)\end{array}$ & & & & \\
\hline$\emptyset$ & $\begin{array}{l}-0.21 \\
(-0.96)\end{array}$ & & & & & & & \\
\hline LNL & 943.59 & 987.61 & 987.35 & 942.81 & 836.53 & 799.21 & 882.23 & 828.73 \\
\hline
\end{tabular}

${ }^{*}{ }^{* *}$ and ${ }^{* * *}$ denote significance at $10 \%, 5 \%$ and $1 \%$ level. The numbers in the () are the $t$-statistic 
Table 5 Results of selection model tests for economic growth during 1992-2016 with human capital

\begin{tabular}{|c|c|c|c|}
\hline $\begin{array}{l}\text { Hypothesis } \\
\mathrm{H}_{0} \text { (restricted } \\
\text { model) }\end{array}$ & $\begin{array}{l}\text { Hypothesis } \mathrm{H}_{1} \\
\text { (unrestricted } \\
\text { model) }\end{array}$ & The test result & $\begin{array}{l}\text { Value of the test } \\
\text { statistic ( } P \text { value) }\end{array}$ \\
\hline \multicolumn{4}{|c|}{$\begin{array}{l}\text { Hausman test (to select the random effects and the fixed effects } \\
\text { model) }\end{array}$} \\
\hline SDM random & SDM fixed & SDM fixed & $H=40.86(0.0000)$ \\
\hline SAR random & SAR fixed & SAR fixed & $H=-4645.28()$ \\
\hline SEM random & SEM fixed & SEM fixed & $H=37.21(0.000)$ \\
\hline \multicolumn{4}{|c|}{ LR test (for nested models) } \\
\hline SAR fixed & SDM fixed & SDM fixed & $\begin{array}{l}L R=98.9886 \\
\quad(0.000)\end{array}$ \\
\hline SEM fixed & SAC fixed & SEM fixed & $\begin{array}{l}\mathrm{LR}=0.8648 \\
\quad(0.9296)\end{array}$ \\
\hline SAR fixed & SAC fixed & SAC fixed & $\begin{array}{l}\mathrm{LR}=303.37 \\
\quad(0.000)\end{array}$ \\
\hline SEM random & GSPRE random & SEM random & $\begin{array}{l}\mathrm{LR}=1.1744 \\
\quad(0.8823)\end{array}$ \\
\hline
\end{tabular}

superior to the random effects model and thus making it more appropriate. Furthermore, the results of the LR test for selecting the more appropriate model are shown in Table 4. Based on the Hausman test, there are four models for the LR test and thus comparisons could be made between the fixed SAR and fixed SDM models, between the fixed SEM and fixed SAC models, between the fixed SAR and fixed SAC models and between the random SEM and random GSPRE models. Based on the results, the SEM, SAC and SDM models had one fixed state and one random; when in random state, SEM was selected. Based on the Hausman test, the last model was rejected because it had random effects. $R^{2}$ was $0.1718,0.1741$ and 0.0087 in the SAC, SEM and SDM models, respectively. Since the SEM model had the greatest $R^{2}$, it was more likely to be accepted and consequently selected as the more appropriate model. In fact, the "fixed SEM model," compared to other spatial models better explains the impact of economic growth and the spatial correlation.
According to Table 7, based on the SEM model, the coefficient of the log of GDP, the gross fixed capital formation and the growth rate labor force are negative, positive and negative, respectively. The coefficient of human capital is not significant. When measuring the factors affecting economic growth such as the formation of gross fixed capital formation and growth rate labor force, to avoid the heterogeneity variance, it is necessary to determine the position and proximity of the desired location which the model measures. The significance of these coefficients implies that the meaning of spatial correlation is based on geographical location. Furthermore, the spatial correlation coefficient, $\lambda$, indicates that the value of this coefficient is statistically significant and positive indicating that the geographical dimension is of particular importance among the countries surveyed. If the average weighted economic growth of neighboring countries increases by $1 \%$, its economic growth will increase by $0.08 \%$.

The results of the recognition spatial test (log likelihood function) in Table 6 show that zero hypotheses (lack of existence of spatial correlation) was rejected, and spatial autocorrelation in these 5 years existed. In other words, it indicates the existence of spatial effects of this group of countries. According to the values of those tests, the SDM model was accepted.

Table 7 shows that by considering the geographical distance from models with human capital, the coefficient of the $\log$ of the GDP was significant and negative in 1995, 2005, 2010 and 2015. The coefficient of the gross fixed capital formation (constant 2010 US\$) was significant and negative in 1995 and 2000 and significant and positive in 2005, 2010 and 2015. The coefficient of the growth rate of labor force was significant and negative in 2000 and significant and positive in 2015. The coefficient of human capital was significant and positive in 2000 . Table 7 shows that by considering the geographical distance from models without human capital, the coefficient of the log of the GDP was significant and negative in 2005 and 2015. The coefficient of the gross fixed capital formation (constant 2010 US\$) was significant and negative in

Table 6 Recognition spatial test (log likelihood function)

\begin{tabular}{|c|c|c|c|c|c|c|c|c|}
\hline & \multicolumn{4}{|c|}{ With human capital } & \multicolumn{4}{|c|}{ Without human capital } \\
\hline & SAC & SDM & SEM & SAR & SAC & SDM & SEM & SAR \\
\hline 1995 & 41.5919 & 44.0772 & 41.5877 & 41.5912 & 40.0270 & 42.8049 & 40.0139 & 39.8424 \\
\hline 2000 & 49.6891 & 56.6342 & 47.4747 & 49.2771 & 46.9620 & 53.3574 & 46.4605 & 46.0720 \\
\hline 2005 & 53.0420 & 53.6073 & 50.8721 & 50.6797 & 50.7562 & 51.2801 & 50.3503 & 48.9709 \\
\hline 2010 & 41.8866 & 43.8628 & 40.7699 & 41.4725 & 41.7530 & 41.8930 & 40.6476 & 41.0188 \\
\hline 2015 & 45.4213 & 51.4555 & 45.2542 & 45.0797 & 44.2959 & 45.5811 & 44.1382 & 44.2922 \\
\hline
\end{tabular}


Table 7 The estimation the SDM model results

\begin{tabular}{|c|c|c|c|c|c|c|c|c|c|c|}
\hline \multirow[t]{2}{*}{ Variable } & \multicolumn{5}{|c|}{ With human capital } & \multicolumn{5}{|c|}{ Without human capital } \\
\hline & 1995 & 2000 & 2005 & 2010 & 2015 & 1995 & 2000 & 2005 & 2010 & 2015 \\
\hline Constant & $\begin{array}{l}0.37^{* * * *} \\
(3.32)\end{array}$ & $\begin{array}{l}0.39 * * * \\
(4.08)\end{array}$ & $\begin{array}{l}0.13 \\
(1.19)\end{array}$ & $\begin{array}{l}-0.26 \\
(-1.33)\end{array}$ & $\begin{array}{l}0.18^{*} \\
(1.81)\end{array}$ & $\begin{array}{l}0.33^{* * *} \\
(3.22)\end{array}$ & $\begin{array}{l}0.34^{* * *} \\
(3.11)\end{array}$ & $\begin{array}{l}0.12 \\
(0.98)\end{array}$ & $\begin{array}{l}0.001 \\
(0.00)\end{array}$ & $\begin{array}{l}0.11 \\
(1.11)\end{array}$ \\
\hline $\operatorname{LNGDP}(t-1)$ & $\begin{array}{l}-0.01^{* *} \\
(-1.70)\end{array}$ & $\begin{array}{l}-0.004 \\
(-0.60)\end{array}$ & $\begin{array}{l}-0.04^{* *} \\
(-2.51)\end{array}$ & $\begin{array}{l}-0.03^{*} \\
(-1.76)\end{array}$ & $\begin{array}{l}-0.04^{* * *} \\
(-4.24)\end{array}$ & $\begin{array}{l}-0.004 \\
(-0.63)\end{array}$ & $\begin{array}{l}0.005 \\
(0.89)\end{array}$ & $\begin{array}{l}-0.02^{* *} \\
(-2.41)\end{array}$ & $\begin{array}{l}-0.005 \\
(-0.61)\end{array}$ & $\begin{array}{l}-0.02^{* * *} \\
(-3.51)\end{array}$ \\
\hline LN capital & $\begin{array}{l}-0.01^{* *} \\
(-2.28)\end{array}$ & $\begin{array}{l}-0.02^{* * *} \\
(-3.10)\end{array}$ & $\begin{array}{l}0.01^{* *} \\
(2.51)\end{array}$ & $\begin{array}{l}0.02^{* *} \\
(2.23)\end{array}$ & $\begin{array}{l}0.01^{* *} \\
(3.10)\end{array}$ & $\begin{array}{l}-0.011^{* *} \\
(-2.23)\end{array}$ & $\begin{array}{l}-0.01^{* * *} \\
(-2.92)\end{array}$ & $\begin{array}{l}0.007 \\
(1.50)\end{array}$ & $\begin{array}{l}0.006 \\
(0.79)\end{array}$ & $\begin{array}{l}0.007 \\
(1.65)\end{array}$ \\
\hline LN human capital & $\begin{array}{l}0.06 \\
(1.37)\end{array}$ & $\begin{array}{l}0.05^{*} \\
(1.85)\end{array}$ & $0.04(0.43)$ & $\begin{array}{l}0.05 \\
(0.84)\end{array}$ & $\begin{array}{l}-0.008 \\
(-0.21)\end{array}$ & & & & & \\
\hline$(N+0.05)$ & $\begin{array}{l}-0.005 \\
(-0.74)\end{array}$ & $\begin{array}{l}-0.01^{* * *} \\
(-4.62)\end{array}$ & $\begin{array}{l}-0.003 \\
(-0.46)\end{array}$ & $\begin{array}{l}0.003 \\
(0.60)\end{array}$ & $\begin{array}{l}0.01^{*} \\
(1.75)\end{array}$ & $\begin{array}{l}0.002 \\
(0.42)\end{array}$ & $\begin{array}{l}-0.009^{* * *} \\
(-3.93)\end{array}$ & $\begin{array}{l}-0.004 \\
(-0.84)\end{array}$ & $\begin{array}{l}-0.001 \\
(-0.31)\end{array}$ & $\begin{array}{l}0.006 \\
(0.86)\end{array}$ \\
\hline $\operatorname{LNGDP}(t-1)^{*} W$ & $\begin{array}{l}-0.003^{* *} \\
(-1.09)\end{array}$ & $\begin{array}{l}-0.005 \\
(-0.87)\end{array}$ & $\begin{array}{l}-0.02^{*} \\
(-1.83)\end{array}$ & $\begin{array}{l}-0.001 \\
(-0.25)\end{array}$ & $\begin{array}{l}-0.01 \\
(-1.64)\end{array}$ & $\begin{array}{l}-0.005^{* *} \\
(-2.09)\end{array}$ & $\begin{array}{l}-0.0004 \\
(-0.09)\end{array}$ & $\begin{array}{l}-0.004 \\
(-0.78)\end{array}$ & $\begin{array}{l}-0.001 \\
(-0.20)\end{array}$ & $\begin{array}{l}0.003 \\
(0.64)\end{array}$ \\
\hline Capital LN* W & $\begin{array}{l}0.003^{* *} \\
(1.71)\end{array}$ & $\begin{array}{l}0.003^{* *} \\
2.43\end{array}$ & $\begin{array}{l}0.003 \\
(1.30)\end{array}$ & $\begin{array}{l}-0.004 \\
(-1.51)\end{array}$ & $\begin{array}{l}-0.001 \\
(-0.46)\end{array}$ & $\begin{array}{l}0.003^{* *} \\
(2.16)\end{array}$ & $\begin{array}{l}0.002 \\
1.31\end{array}$ & $\begin{array}{l}0.002 \\
1.06\end{array}$ & $\begin{array}{l}0.0003 \\
(0.14)\end{array}$ & $\begin{array}{l}-0.001 \\
(-0.47)\end{array}$ \\
\hline$W^{*}$ LN human capital & $\begin{array}{l}-0.01 \\
(-0.66)\end{array}$ & $\begin{array}{l}0.003 \\
(0.13)\end{array}$ & $\begin{array}{l}0.09 \\
(1.40)\end{array}$ & $\begin{array}{l}0.06^{* *} \\
(1.98)\end{array}$ & $\begin{array}{l}0.08^{* * *} \\
(3.05)\end{array}$ & & & & & \\
\hline$(N+0.05)^{*} W$ & $\begin{array}{l}-0.003 \\
(-1.29)\end{array}$ & $\begin{array}{l}-0.005 \\
(-0.96)\end{array}$ & $\begin{array}{l}0.009 \\
(1.55)\end{array}$ & $\begin{array}{l}0.005 \\
(1.38)\end{array}$ & $\begin{array}{l}-0.005 \\
(-1.18)\end{array}$ & $\begin{array}{l}-0.004 \\
(-1.49)\end{array}$ & $\begin{array}{l}-0.009^{* *} \\
(-2.19)\end{array}$ & $\begin{array}{l}-0.001 \\
(-0.47)\end{array}$ & $\begin{array}{l}-0.0002 \\
(-0.05)\end{array}$ & $\begin{array}{l}-0.005 \\
(-1.49)\end{array}$ \\
\hline$\rho$ & $\begin{array}{l}-0.1 \\
(-0.64)\end{array}$ & $\begin{array}{l}-0.64^{* * *} \\
(-2.96)\end{array}$ & $\begin{array}{l}-0.76^{* * *} \\
(-3.17)\end{array}$ & $\begin{array}{l}-0.05 \\
(-0.39)\end{array}$ & $\begin{array}{l}-0.6^{* * *} \\
(-2.85)\end{array}$ & $\begin{array}{l}-0.10 \\
(-0.65)\end{array}$ & $\begin{array}{l}-0.66^{* * *} \\
(-2.91)\end{array}$ & $\begin{array}{l}-0.72^{* * *} \\
(-2.79)\end{array}$ & $\begin{array}{l}-0.08 \\
(-0.54)\end{array}$ & $\begin{array}{l}-0.14 \\
(-1.17)\end{array}$ \\
\hline$\lambda$ & $\begin{array}{l}0.01^{* * *} \\
(4.25)\end{array}$ & $\begin{array}{l}0.01^{* * *} \\
(5.12)\end{array}$ & $\begin{array}{l}0.02^{* * *} \\
(5.57)\end{array}$ & $\begin{array}{l}0.02^{* * *} \\
(4.55)\end{array}$ & $\begin{array}{l}0.01^{* * *} \\
(4.70)\end{array}$ & $\begin{array}{l}0.02^{* * *} \\
4.20\end{array}$ & $\begin{array}{l}0.01^{* * *} \\
(5.11)\end{array}$ & $\begin{array}{l}0.02^{* * *} \\
(5.44)\end{array}$ & $\begin{array}{l}0.02^{* * *} \\
(4.47)\end{array}$ & $\begin{array}{l}0.01^{* * *} \\
(4.55)\end{array}$ \\
\hline
\end{tabular}

1995 and 2000. The coefficient of the growth rate labor force was significant and negative in 2000 . The coefficient of the spatial autoregression $(\rho)$ was significant and negative in models with human capital in 2000, 2005, 2010 and 2015 and without human capital in 2000, 2005 and 2010.

According to Table 8, in both models direct, effects of the $\operatorname{GDP}_{(t-1)}$ and the gross fixed capital formation are negative showing that an increase in $\mathrm{GDP}_{(t-1)}$ and gross fixed capital formation in one country results in a decrease in economic growth in other countries. The indirect effects (spillover) of both models are positive, illustrating that increasing $\mathrm{GDP}_{(t-1)}$ and gross fixed capital formation in one country leads to economic growth in other countries and thus the effects are positive. The total effects show that if $\mathrm{GDP}_{(t-1)}$ and gross fixed capital formation of one country increase, economic growth of all countries would decrease by 0.0156 and 0.0111 in the model with human capital and by 0.0041 and 0.0119 in the model without human capital, respectively. The direct effect, indirect effect (spillover) and total effect of all variables in the model with human capital growth rate of labor force was negative on economic growth showing that an increase in growth rate of labor force in one country results in a decrease of 0.0054 of economic growth in all countries. In the model without human capital, direct

Table 8 Direct and indirect effects of the SDM model in 1995

\begin{tabular}{|c|c|c|c|c|c|c|c|c|}
\hline & \multicolumn{4}{|c|}{ With human capital } & \multicolumn{4}{|c|}{ Without human capital } \\
\hline & Indirect effect & Direct effect & Total effect & $\beta$ & Indirect effect & Direct effect & Total effect & $\beta$ \\
\hline $\left.\operatorname{GDP}_{t-1}\right)$ & 0.0054 & -0.0211 & -0.0156 & -0.0144 & 0.0015 & -0.0056 & -0.0041 & -0.0038 \\
\hline Capital & 0.0039 & -0.0150 & -0.0111 & -0.0103 & 0.0043 & -0.0162 & -0.0119 & -0.0110 \\
\hline Human capital & -0.0215 & 0.0833 & 0.0618 & 0.0571 & - & - & - & - \\
\hline$(N+0.05)$ & -0.0019 & -0.0073 & -0.0054 & -0.0050 & -0.0010 & 0.0036 & 0.0026 & 0.0024 \\
\hline $\operatorname{GDP}(t-1) * W$ & 0.0011 & -0.0043 & -0.0032 & -0.0030 & 0.0021 & -0.0080 & -0.0059 & -0.0054 \\
\hline Capital* W & -0.0010 & 0.0039 & 0.0029 & 0.0027 & -0.0012 & 0.0045 & 0.0033 & 0.0030 \\
\hline Human capital* $W$ & 0.0052 & -0.0200 & -0.0149 & -0.0137 & - & - & - & - \\
\hline$(N+0.05)^{*} W$ & 0.0013 & -0.0049 & -0.0037 & -0.0034 & 0.0015 & -0.0055 & -0.0040 & -0.0037 \\
\hline
\end{tabular}


effects of growth rate of labor force were positive which indicates that the increase in growth rate of labor force in one country leads to increases in economic growth of all countries. The indirect effect (spillover) was negative as increasing growth rate of labor force in one country leads to decreased economic growth in other countries. The total effects show that if growth rate labor force in one country increases, economic growth of all countries would increase by 0.0026 . The direct effect of human capital was positive, indicating increasing economic growth of all countries when human capital increases in one country. The indirect effect (spillover) was negative as with increasing human capital in one country, economic growth in other countries decreases, thus having a negative effect on other countries. If the total effects show human capital in one country increasing, economic growth of all countries would increase by 0.0618 .

According to Table 9, in the model with human capital, direct effects of $\mathrm{GDP}_{(t-1)}$, gross fixed capital formation and growth rate of labor force were negative indicating that an increase in $\mathrm{GDP}_{(t-1)}$, gross fixed capital formation and growth rate of labor force in one country results in a decrease in economic growth in all countries. The indirect effects (spillover) in the model with human capital were positive as increasing $\mathrm{GDP}_{(t-1)}$, gross fixed capital formation and growth rate of labor force in one country leads to a rise in economic growth in other countries, thus having a positive effect on other countries. The total effects illustrate that if $\mathrm{GDP}_{(t-1)}$, gross fixed capital formation and growth rate of labor force in one country increased, they would decrease by $0.0046,0.0196$ and 0.0139 in other countries, respectively, and thus lead to a decline in economic growth. The direct effect of human capital is positive, indicating that an increase in human capital in one country results in an increase in economic growth of all countries. The indirect effect (spillover) was negative as increasing human capital in one country will decrease economic growth in other countries. The total effects represent that if human capital in one country increases, economic growth of all countries would increase by 0.0682 . In the model without human capital, direct effects of gross fixed capital formation and growth rate of labor force were negative, illustrating that an increase in gross fixed capital formation and growth rate of labor force in one country leads to a decrease in economic growth of all countries. The indirect effects (spillover) in the model without human capital were positive since increasing gross fixed capital formation and growth rate of labor force in one country intensifies economic growth in other countries, thus having a positive effect. The total effects demonstrate that if gross fixed capital formation and growth rate of labor force in one country increase, they would decrease by 0.0188 and 0.0119 in other countries, respectively, and consequently lead to a decline in economic growth. The direct effect of $\operatorname{GDP}_{(t-1)}$ is positive, indicating that an increase in $\mathrm{GDP}_{(t-1)}$ in one country results in an increase in economic growth of all countries. The indirect effect (spillover) was negative as increasing $\mathrm{GDP}_{(t-1)}$ in one country decreased economic growth in other countries, thus having a negative impact. The total effects show that if $\mathrm{GDP}_{(t-1)}$ in one country increases, economic growth of all countries would increase by 0.0070 .

According to Table 10, in the model with human capital, direct effects of gross fixed capital formation and human capital were positive indicating that an increase in gross fixed capital formation and human capital in one country leads to an increase in economic growth of all countries. The indirect effects (spillover) were negative as increasing gross fixed capital formation and human capital in one country results in declined economic growth in other countries. The total effects show that if gross fixed capital formation and human capital in one country increase, they would increase by 0.0163 and 0.0556 in other countries, respectively, and lead to economic growth. In both models, direct effects of $\mathrm{GDP}_{(t-1)}$ and

Table 9 Direct and indirect effects of the SDM model in 2000

\begin{tabular}{|c|c|c|c|c|c|c|c|c|}
\hline & \multicolumn{4}{|c|}{ With human capital } & \multicolumn{4}{|c|}{ Without human capital } \\
\hline & Indirect effect & Direct effect & Total effect & $\beta$ & Indirect effect & Direct effect & Total effect & $\beta$ \\
\hline $\left.\operatorname{GDP}_{t-1}\right)$ & 0.0099 & -0.0144 & -0.0046 & -0.0035 & -0.0157 & 0.0227 & 0.0070 & 0.0054 \\
\hline Capital & 0.0422 & -0.0619 & -0.0196 & -0.0151 & 0.0420 & -0.0609 & -0.0188 & -0.0145 \\
\hline Human capital & -0.1468 & 0.2150 & 0.0682 & 0.0526 & 0.0266 & -0.0386 & -0.0119 & -0.0092 \\
\hline$(N+0.05)$ & 0.0299 & -0.0438 & -0.0139 & -0.0107 & - & - & - & - \\
\hline $\left.\mathrm{GDP}_{(t-1}\right) * W$ & 0.0148 & -0.0217 & -0.0069 & -0.0053 & 0.0011 & -0.0016 & -0.0005 & -0.0004 \\
\hline Capital* $W^{*}$ & -0.0095 & 0.0139 & 0.0044 & 0.0034 & -0.0062 & 0.0090 & 0.0028 & 0.0021 \\
\hline Human capital* $W$ & -0.0085 & 0.0124 & 0.0039 & 0.0030 & - & - & - & - \\
\hline$(N+0.05)^{*} W$ & 0.0138 & -0.0203 & -0.0064 & -0.0050 & 0.0261 & -0.0378 & -0.0117 & -0.0090 \\
\hline
\end{tabular}


Table 10 Direct and indirect effects of the SDM model in 2005

\begin{tabular}{|c|c|c|c|c|c|c|c|c|}
\hline & \multicolumn{4}{|c|}{ With human capital } & \multicolumn{4}{|c|}{ Without human capital } \\
\hline & Indirect effect & Direct effect & Total effect & $\beta$ & Indirect effect & Direct effect & Total effect & $\beta$ \\
\hline $\left.\operatorname{GDP}_{(t-1}\right)$ & 0.1323 & -0.1825 & -0.0503 & -0.0388 & 0.0672 & -0.0948 & -0.0276 & -0.0212 \\
\hline Capital & -0.0428 & 0.0591 & 0.0163 & 0.0126 & -0.0232 & 0.0327 & 0.0095 & 0.0073 \\
\hline Human capital & -0.1463 & 0.2019 & 0.0556 & 0.0430 & - & - & - & - \\
\hline$(N+0.05)$ & 0.0119 & -0.0164 & -0.0045 & -0.0035 & 0.0115 & -0.0162 & -0.0047 & -0.0036 \\
\hline $\left.\operatorname{GDP}_{t-1}\right) * W$ & 0.0743 & -0.1025 & -0.0282 & -0.0218 & 0.0127 & -0.0179 & -0.0052 & -0.0040 \\
\hline Capital *W & -0.0094 & 0.0129 & 0.0036 & 0.0028 & -0.0075 & 0.0106 & 0.0031 & 0.0024 \\
\hline Human capital* $W$ & -0.3209 & 0.4428 & 0.1219 & 0.0942 & - & - & - & - \\
\hline$(N+0.05)^{*} W$ & -0.0311 & 0.0429 & 0.0118 & 0.0091 & 0.0032 & -0.0045 & -0.0013 & -0.0010 \\
\hline
\end{tabular}

growth rate of labor force were negative, indicating that an increase in $\mathrm{GDP}_{(t-1)}$ and growth rate of labor force in one country results in a decrease in economic growth of all countries. The indirect effects (spillover) of both models were positive as increasing $\mathrm{GDP}_{(t-1)}$ and growth rate of labor force in one country leads to economic growth in other countries, thus having a positive effect. The total effects illustrate that if $\mathrm{GDP}_{(t-1)}$ and growth rate of labor force in one country increase, they would decrease by 0.0503 and 0.0045 in the model with human capital and by 0.0276 and 0.0047 in the model without human capital, respectively, leading to a decline of economic growth in all countries. In the model without human capital, direct effects of gross fixed capital formation were positive, indicating that an increase in the gross fixed capital formation of one country increases economic growth of all countries. The indirect effect (spillover) was negative as increasing gross fixed capital formation of one country decreased economic growth in other countries and consequently a negative effect on other countries. The total effects demonstrate that if the gross fixed capital formation of one country increase, economic growth of all countries would increase by 0.0095 .
According to Table 11, in the model with human capital, direct effects of gross fixed capital formation and human capital were positive, implying that an increase in gross fixed capital formation and human capital in one country increases economic growth of all countries. The indirect effects (spillover) were negative as increasing gross fixed capital formation and human capital in one country decreased economic growth in other countries. The total effects showed that if gross fixed capital formation and human capital in one country increased, they would increase by 0.0257 and 0.0557 in other countries, respectively. In the model with human capital, direct effects of $\mathrm{GDP}_{(t-1)}$ were negative, implying that that an increase in $\mathrm{GDP}_{(t-1)}$ in one country results in a decrease in economic growth in other countries. The indirect effects (spillover) were positive since increasing $\mathrm{GDP}_{(t-1)}$ in one country increased economic growth in other countries. The total effects demonstrate that if $\mathrm{GDP}_{(t-1)}$ in one country increased, economic growth of all countries would decrease by 0.0309 . In the model with human capital, direct effects of growth rate of labor force were positive, indicating that the increase in growth rate of labor force in one country leads to increased economic

Table 11 Direct and indirect effects of the SDM model in 2010

\begin{tabular}{|c|c|c|c|c|c|c|c|c|}
\hline & \multicolumn{4}{|c|}{ With human capital } & \multicolumn{4}{|c|}{ Without human capital } \\
\hline & Indirect effect & Direct effect & Total effect & $\beta$ & Indirect effect & Direct effect & Total effect & $\beta$ \\
\hline $\left.\operatorname{GDP}_{t-1}\right)$ & 0.0055 & -0.0365 & -0.0309 & -0.0296 & 0.0016 & -0.0074 & -0.0058 & -0.0054 \\
\hline Capital & -0.0046 & 0.0304 & 0.0257 & 0.0246 & -0.0017 & 0.0080 & 0.0063 & 0.0059 \\
\hline Human capital & -0.0100 & 0.0657 & 0.0557 & 0.0533 & - & - & - & - \\
\hline$(N+0.05)$ & -0.0005 & 0.0033 & 0.0028 & 0.0027 & 0.0004 & -0.0019 & -0.0015 & -0.0014 \\
\hline $\left.\operatorname{GDP}_{t-1}\right) * W$ & 0.0002 & -0.0015 & -0.0013 & -0.0012 & 0.0003 & -0.0015 & -0.0012 & -0.0011 \\
\hline Capital* W & 0.0008 & -0.0053 & -0.0045 & -0.0043 & -0.0001 & 0.0004 & 0.0003 & 0.0003 \\
\hline Human capital* $W$ & -0.0108 & 0.0710 & 0.0603 & 0.0576 & - & - & - & - \\
\hline$(N+0.05) * W$ & -0.0009 & 0.0062 & 0.0053 & 0.0050 & 0.0000 & -0.0002 & -0.0002 & -0.0002 \\
\hline
\end{tabular}


growth of all countries. The indirect effects (spillover) were negative as increasing growth rate of labor force in one country decreased economic growth in other countries, thus having a negative effect on other countries. The total effects showed that if gross fixed capital formation and human capital in one country rose, economic growth of all countries would increase by 0.0028 .

In the model without human capital, direct effects of gross fixed capital formation were positive, indicating that with an increase in the gross fixed capital formation of one country, economic growth also occurred in other countries. The indirect effects (spillover) were negative as an increase in gross fixed capital formation and human capital in one country leads to a reduction in economic growth of other countries. The total effects illustrate that if gross fixed capital formation and human capital in one country increased, economic growth of all countries would increase by 0.0063 . In the model without human capital, direct effects of $\mathrm{GDP}_{(t-1)}$ and growth rate of labor force were negative, indicating that an the increase in $\mathrm{GDP}_{(t-1)}$ and growth rate of labor force in one country leads to a decrease of economic of economic growth in all countries. The indirect effects (spillover) were positive since an increase in $\operatorname{GDP}_{(t-1)}$ and growth rate of labor force in one country results in economic growth in other countries. The total effects demonstrate that if $\operatorname{GDP}_{(t-1)}$ and growth rate of labor force in one country increase, economic growth of all countries will decrease by 0.0058 and 0.0015 , respectively.

According to Table 12, in both models, direct effects of gross fixed capital formation and growth rate of labor force were positive which indicate that with the increase in gross fixed capital formation and growth rate of labor force in one country, an increase occurs in the economic growth of all countries. The indirect effects (spillover) of both models were negative since increased gross fixed capital formation and growth rate of labor force in one country lead to decreased economic growth in other countries. The total effects show that if gross fixed capital formation and growth rate of labor force in one country increased, they would increase by 0.0173 and 0.0173 in the model with human capital and by 0.0072 and 0.0061 in the model without human capital, respectively. In the model with human capital, direct effects of $\mathrm{GDP}_{(t-1)}$ and human capital were negative indicating that an increase in $\operatorname{GDP}_{(t-1)}$ and human capital in one country consequently decrease economic growth of all countries. The indirect effects (spillover) were positive as increasing $\mathrm{GDP}_{(t-1)}$ and human capital in one country leads to economic growth in other countries. The total effects show that if $\mathrm{GDP}_{(t-1)}$ and human capital in one country increase, they would decrease by 0.0536 and 0.0107 in all countries, respectively, resulting in declined economic growth. In model without human capital, direct effects of $\mathrm{GDP}_{(t-1)}$ were negative, illustrating that an increase in $\mathrm{GDP}_{(t-1)}$ in one country results in a decrease in economic growth in all countries. The indirect effects (spillover) were positive as increasing $\mathrm{GDP}_{(t-1)}$ in one country increased economic growth in other countries. The total effects demonstrated that if $\mathrm{GDP}_{(t-1)}$ in one country increased, economic growth of all countries would increase by 0.0257 .

\section{Results and discussion}

Spatial dynamic panel data model and spatial cross-sectional data approach for estimating the augmented Solow growth model with a sample of 19 ASIA countries over the period 1992-2016 were employed. The findings indicated that there was a positive spillover effect of growth from one country to its neighboring countries in the spatial dynamic panel data model and a negative spillover effect of the growth of one country to its neighboring countries in the spatial cross-sectional data model. This implied that traditional estimation techniques could lead to biased estimated parameters due to disregard of spatial spillover effects of variables. Spatial econometric models

Table 12 Direct and indirect effects of the SDM model in 2015

\begin{tabular}{|c|c|c|c|c|c|c|c|c|}
\hline & \multicolumn{4}{|c|}{ With human capital } & \multicolumn{4}{|c|}{ Without human capital } \\
\hline & Indirect effect & Direct effect & Total effect & $\beta$ & Indirect effect & Direct effect & Total effect & $\beta$ \\
\hline $\left.\operatorname{GDP}_{t-1}\right)$ & 0.1080 & -0.1616 & -0.0536 & -0.0415 & 0.0124 & -0.0381 & -0.0257 & -0.0231 \\
\hline Capital & -0.0349 & 0.0523 & 0.0173 & 0.0134 & -0.0035 & 0.0107 & 0.0072 & 0.0065 \\
\hline Human capital & 0.0216 & -0.0324 & -0.0107 & -0.0083 & - & - & - & - \\
\hline$(N+0.05)$ & -0.0348 & 0.0521 & 0.0173 & 0.0134 & -0.0030 & 0.0091 & 0.0061 & 0.0055 \\
\hline $\left.\operatorname{GDP}_{(t-1}\right) * W$ & 0.0270 & -0.0405 & -0.0134 & -0.0104 & -0.0014 & 0.0042 & 0.0028 & 0.0025 \\
\hline Capital* W & 0.0023 & -0.0034 & -0.0011 & -0.0009 & 0.0004 & -0.0013 & -0.0009 & -0.0008 \\
\hline Human capital ${ }^{*} W$ & -0.2201 & 0.3293 & 0.1092 & 0.0845 & - & - & - & - \\
\hline$(N+0.05)^{*} W$ & 0.0142 & -0.0212 & -0.0070 & -0.0054 & 0.0026 & -0.0079 & -0.0053 & -0.0048 \\
\hline
\end{tabular}


offer means to explore whether local economic growth depends on the characteristics of neighboring countries. In the spatial dynamic panel data model, the log of GDP, gross fixed capital formation and growth rate labor force were significant. Log of GDP and growth rate labor force had negative effects on growth, while gross fixed capital formation had positive effects. In spatial cross-sectional data models in both with and without human capital coefficient of log of GDP, gross fixed capital formation and growth rate labor force had a negative effect on economic growth but coefficient of human capital had a positive effect. In spatial cross-sectional data models in the model with the human capital log of GDP, gross fixed capital formation and growth rate labor force had a negative effect on economic growth, but in the model without human capital, human capital log of GDP and human capital had a positive effect. In addition, gross fixed capital formation and growth rate labor force had positive and negative effects on economic growth, respectively.

\section{Conclusions}

When a country invests in technology and improves its technology, the return on investment is greater than the domestic interest that it owns, its neighboring countries benefit and their productivity increases. In other words, improvement in the situation of one or more countries in a region leads to benefits for all the countries in the region and will, in fact, create a positive growth cycle in the region. In addition, with increasing in physical capital, the country's production capacity will be increased and with economic growth, GDP growth will be raised. Capital outflow from countries with high capital stock to low capital stock countries occurs. Moreover, when openness increases, capital flow also rises. The transfer of capital from rich countries to poor countries leads to relatively higher productivity of the labor force in poorer countries. The coefficient of the growth rate of the labor force is negative. When the final productivity of the workforce is zero, the growth rate of the labor force will be negative leading to unemployment in the country; therefore, more of the labor force entering the production process does not increase production. If unemployment in the countries is under consideration or an increase in the production capacity is not as high as the growth rate of the labor force, the increase in the labor force growth rate reduces GDP growth; thus, economic growth is reduced because saturation point is reached and the final production of the workforce will be negative. On the other hand, in the Solow's models, economic growth increases due to the lower returns of capital to the workforce by increasing physical capital and reducing labor force growth rates. When measuring factors affect economic growth such as the formation of gross fixed capital formation and growth rate of labor force, it is necessary to determine the position and proximity of the desired location measured in the model to avoid the heterogeneity variance.

\begin{abstract}
Acknowledgements
Not applicable.

Authors' contributions

SA ensures that original data/original figures/materials/code upon which the submission is based are preserved following best practices in the field so that they are retrievable for reanalysis; confirms that data/figures/materials/ code presentation accurately reflects the original; and foresees and minimizes obstacles to the sharing of data/materials/code described in the work. (AB carried out the molecular genetic studies, participated in the sequence alignment and drafted the manuscript. JY carried out the immunoassays. MT participated in the sequence alignment. ES participated in the design of the study and performed the statistical analysis. FG conceived of the study and participated in its design and coordination and helped to draft the manuscript.) AFM: JY carried out the immunoassays. BJ: JY carried out the immunoassays. All authors read and approved the final manuscript.
\end{abstract}

Funding

No funding was obtained for this research.

Availability of data and materials

All data will be made available and sent journal after acceptance of this paper for publication.

\section{Competing interests}

The authors declare that they have no competing interests.

\section{Author details}

${ }^{1}$ Universite D'Orleans, 45000 Orléans, France. ${ }^{2}$ University of Kurdistan, Sanandaj, Iran.

Received: 23 July 2019 Accepted: 12 March 2020

Published: 18 June 2020

\section{References}

1. Amidi S, Fagheh Majidi A (2020) Geographic proximity, trade and economic growth: a spatial econometrics approach. Ann GIS 26(1):49-63

2. Anselin L, Bera A (1998) Spatial dependence in linear regression models with an introduction to spatial econometrics. In: Ullah A, Giles D (eds) Handbook of applied economics statistics. Marcel Dekker, New York, pp 237-289

3. Atella V, Belotti F, Depalo D, Mortari AP (2014) Measuring spatial effects in the presence of institutional constraints: the case of Italian Local Health Authority expenditure. Reg Sci Urban Econ 49:232-241

4. Baltagi BH (2005) Econometric analysis of panel data, 3rd edn. Wiley, Chichester

5. Barro Robert, Lee Jong-Wha (2013) A new data set of educational attainment in the world, 1950-2010. J Dev Econ 104:184-198

6. Barro RJ, Sala-i-Martin X (1995) Economic growth. Advanced series in economics. McGraw-Hill, London

7. Belotti F, Hughes G, Mortari A P (2013) XSMLE-A command to estimate spatial panel models in Stata. In: German Stata users group meeting, Potsdam, Alemania, pp 1-36

8. Benos N, Karagiannis S, Karkalakos S (2015) Proximity and growth spillovers in European regions: the role of geographical, economic and technological linkages. J Macroecon 43:124-139

9. Brito P (2005) A spatial Solow model with unbounded growth. In: Essays in honour of Antonio Simoes Lopes, pp 277-298

10. Camacho C, Zou B (2004) The spatial Solow model. Econ Bull 18(2):1-11

11. Durusu-Ciftci D, Gokmenoglu KK, Yetkiner H (2018) The heterogeneous impact of taxation on economic development: new insights from a panel cointegration approach. Econ Syst 42(3):503-513 
12. Elhorst JP (2010) Applied spatial econometrics: raising the bar. Spat Econ Anal 5(1):9-28

13. Elhorst JP (2008) Serial and spatial autocorrelation. Econ Lett 100(3):422-424

14. Elhorst JP (2014) Spatial Econometrics from cross-sectional data to spatial panels. Springer, Berlin

15. Erdem E, Yücel AG, Köseoğlu A (2016) Female labour force participation and economic growth: theoretical and empirical evidence. Empir Econ Lett 15(10):985-991

16. Ertur C, Koch W (2007) Growth, technological interdependence and spatial externalities: theory and evidence. J Appl Econom 22(6):1033-1062

17. Feenstra RC, Inklaar R, Timmer MP (2015) The next generation of the Penn World Table. Am Econ Rev 105(10):3150-3182

18. Floch JM, Le Saout R (2016) Economie spatiale: une introduction pratique

19. Guerrini $L$ (2006) The Solow-Swan model with a bounded population growth rate. J Math Econ 42(1):14-21

20. Hsiao C, Sun B (2000) To pool or not to pool panel data. Contrib Econ Anal 244:181-198

21. Islam N (1995) Growth empirics: a panel data approach. Q J Econ 110(4):1127-1170

22. Kelejian HH, Prucha IR (1998) A generalized spatial two-stage least squares procedure for estimating a spatial autoregressive model with autoregressive disturbances. J Real Estate Finance Econ 17(1):99-121

23. Lee LF, Yu J (2012) QML estimation of spatial dynamic panel data models with time varying spatial weights matrices. Spat Econ Anal 7(1):31-74

24. Lesage J (1999) Spatial econometrics. Department of Economics University of Toledo, Toledo
25. LeSage JP, Pace RK (2009) Introduction to spatial econometrics. CRC Press, Boca Raton

26. Mankiw NG, Romer D, Weil DN (1992) A contribution to the empirics of economic growth. Q J Econ 107(2):407-437

27. McMillen DP (1996) One hundred fifty years of land values in Chicago: a nonparametric approach. J Urban Econ 40(1):100-124

28. Neto JPJ, Claeyssen JCR (2015) Capital-induced labor migration in a spatial solow model. J Econ 115(1):25-47

29. Scarpello GM, Ritelli D (2003) The Solow model improved through the logistic manpower growth law. Annali dell'Università di Ferrara 49(1):73-83

30. Solow RM (1956) A contribution to the theory of economic growth. Q J Econ 70(1):65-94

31. Swan TW (1956) Economic growth and capital accumulation. Econ Rec 32(2):334-361

32. Tobler WR (1979) Smooth pycnophylactic interpolation for geographical regions. J Am Stat Assoc 74(367):519-530

33. Yu Ho C, Wang W, Yu J (2013) Growth spillover through trade: a spatial dynamic panel data approach. Econ Lett 120:450-453

34. Yu J, de Jong R, Lee LF (2012) Estimation for spatial dynamic panel data with fixed effects: the case of spatial cointegration. J Econom 167(1):16-37

\section{Publisher's Note}

Springer Nature remains neutral with regard to jurisdictional claims in published maps and institutional affiliations.

\section{Submit your manuscript to a SpringerOpen ${ }^{\circ}$ journal and benefit from:}

- Convenient online submission

- Rigorous peer review

- Open access: articles freely available online

- High visibility within the field

- Retaining the copyright to your article

Submit your next manuscript at springeropen.com 